\title{
MENYEMAI IMPLEMENTASI \\ PENDIDIKAN HUMANISTIK PADA ABAD 21 \\ DALAM KURIKULUM 2013
}

\author{
Barudin \\ MTs Assalafiyyah Mlangi Sleman Yoyakarta \\ barudin81@gmail.com
}

\begin{abstract}
This paper examines the concept of humanistic education oriented to aspects of humanizing humans (in this case students) to be able to develop the potential that exists in themselves. This humanistic theory also contributes to the world of education, known as humanistic education. Humanistic education seeks to develop the individual as a whole through which real learning. Along with the changes and demands of the times in the arena of globalization 21st century struggles, today there are concerns about the destruction of humanity and the vagueness of human values. To anticipate this, humanist education becomes an alternative approach that can be applied in education. The author concludes that the concept of humanist education is suitable to be applied in learning, especially in encouraging the development of affection, namely the human need to get a good response or a warm treatment from others.
\end{abstract}

Keywords: Implementation, humanistic education, curriculum 2013.

\section{Pendahuluan}

Pengaruh globalisasi sangat terasa sekali. Kemajuan ilmu pengetahuan dan merebaknya perkembangan teknologi mulai mengeser nilai-nilai kemanusian. Dalam dunia pendidikan, hal tersebut sangat berpengaruh besar. Peran orang tua dan guru sebagai pendidik perlahan mulai berkurang. Oleh karena itu, diperlukan paradigma baru untuk menjawab tantangan dalam mempersiapkan 
seorang anak untuk menjalani kehidupan yang akan dilaluinya.

Peran pendidikan mempunyai pengaruh besar terhadap kemajuan suatu Bangsa. Kualitas pendidikan dipengaruhi oleh sistem yang baik. Terlebih saat ini kita sudah memasuki masa abad 21 dimana perkembangan-perkembangan ilmu pengetahuan dan tehnologi berkembang dengan sangat pesat. Pada abad 21 setiap orang dapat dengan mudah mengakses informasi dari belahan dunia manapun. Disamping itu, era globalisasi sangat menuntut suatu bangsa untuk dapat bersaing dengan bangsa lain dalam berbagai bidang. Dunia pendidikan juga perlu berbenah sesuai dengan kemajuan zaman dan kemajuan teknologi. Agar tercapai kualitas yang baik, maka diperlukan usaha yang maksimal, seperti: memaksimalkan daya saing, memiliki kompetensi yang memadai dalam mendukung perubahan pendidikan. Guru memiliki peran besaar dalam mengantarkan peserta didikperan guru menjadi semakin berat. Guru harus mampu mengantarkan peserta didik agar menjadi pribadi yang unggul, dan siap menghadapi era pada abad ini. Kompetensi guru harus selalu dikembangkan dan selalu didukung dengan kemampuan menggunakan teknologi. Disamping itui guru harus mampu merancang materi yang diajarkan mempunyai hubungan erat dengan dunia nyata yang dialami oleh peserta didik, sehingga peserta didik mampu untuk mengaplikasikan materi yang didapatkan dalam pembelajaran dalam kehidupan sehariharinya.

Dalam proses pendidikan sering kali timbul berbagai kendala. Kendala tersebutbisaberupakondisi pembelajaranyang membosankan, ada sebagian siswa yang kurang memperhatikan, ada yang tidur tidak mau mendengarkan penjelasan gurunya, dan lain sebagainya. Sebagian guru menganggap kejadian tersebut menjadi kendala yang membuat pembelajaran menjadi kurang nyaman, sehingga tak jarang muncul justifikasi guru menganggap beberapa kelas menjadi kelas yang sulit untuk dikendalikan. Seharusnya justifikasi tidak dilakukan oleh guru. Kendala tersebut seharusnya justru mendorong guru untuk bias menemukan pendekatan yang dapat memberikan chemistry bagi guru dan peserta didik sehingga dalam pembelajaran terjalin hubungan yang baik. 
Sugiarto (2008:343) Menyatakan proses pendidikan akan terjadi bila ada guru dan peserta didik, guru memberikan ilmu kepada pesereta didik dan peserta didik akan berkembang dengan ilmu dan bimbingan guru. Setiap peserta didik mempunyai kepribadian yang unik. Guru akan mengetahui perilaku-perilaku unik tersebut dengan cara melakukan pendekatan kepada peserta didik.

Salah satu dari pendekatan yang dapat diterapkan adalah pendidikan yang humanis. Konsep humanistik ini mengajarkan manusia memiliki rasa kemanusiaan yang mendalam. Konsep ini dapat dimulai dari perlakuan seorang guru terhadap peserta didik dalam proses belajar dan mengajar. Guru harus mampu menghilangkan rasa egois, otoriter, individualis dan tidak semena-mena terhadap peserta didik. Konsep dasar pendidikan humanistik merupakan pendidikan yang memandang manusia sebagai makhluk ciptaan Allah dengan fitrah-fitrah tertentu untuk dikembangkan secara optimal. Dengan demikian pendidikan humanistik tentu tidak dapat dipisahkan dengan psikologi humanistik. Paham psikologi humanistik inilah yang diyakini oleh beberapa ahli menjadi dasar atau munculnya konsep pendidikan humanistik. Aliran ini yang peningkatan kualitas manusia melalui penghargaan potensi positif yang ada pada manusia seiring dengan perubahan dan tuntutan zaman. Dengan adanya perubahan dalam strategi pendidikan dari waktu ke waktu, humanistik ini memberikan arahan yang signifikan dalam mencapai tujuan ini. Psikologi humanistik membantu upaya perbaikan, salah satunya dengan pendekatan humanistik. Pendekatan humanistik dalam pendidikan lebih menekankan pada ranah kognitif, afektif, dan psikomotorik pada peserta didik. Dalam prakteknya peserta didik diberi pengalaman belajar, diakui, diterima, dimanusiakan sehingga pada akhirnya peserta didik menjadi optimis dan sukses.

Pendidikan humanistik mempunyai hakikat untuk memanusiakan manusia, dimana setiap individu manusia mempunyai cipta, rasa dan karsa. Pendidikan ini harus dikembangkan sebagai prinsip untuk keberhasilan pendidikan. Proses pendidikan dapat dikatakan berhasil apabila orang yang belajar mampu untuk memahami diri dan lingkungannya. Dengan kata lain, "si pembelajar (peserta didik) dalam 


\section{eL-Tarbawj Barudin}

proses belajar harus berusaha agar lambat laun ia mampu mencapai aktualitas diri dengan sebaik-baiknya" Sukardjo (2009:56).

\section{Pembahasan}

Menurut Dinn Wahyudin (2008:51) pendidikan merupakan kegiatan yang kompleks dan meliputi berbagai komponen yang berkaitan dengan erat satu sama lain. Pendidikan adalah gejala semesta (fenomena universal) dan berlangsung sepanjang hayat manusia, dimanapun manusia berada. Pendidikan sebagai usaha sadar bagi pengembangan manusia dan masyarakat, berusaha kearah yang lebih sistematik maka pasti mendasarkan pada landasan pemikiran tertentu.

Di samping itu, Mas'ud (2004:135) mengemukakan humanisme merupakan potensikekuatanindividudalam rangkauntukmendekatkan diri kepada Tuhan serta mampu memecahkan permasalahan sosial. Pandangan ini lebih menitikberatkan pada proses penyempurnaan individu.

Senada dengan itu, Rahman (2002:135) berpendapat bahwa pendidikan humanistik dalam Islam adalah memaknai manusia sebagai individu yang diberi kebebasan oleh Tuhan untuk mengembangkan potensi yang dimiliki dengan memperhatikan kedudukannya sebagai makhluk relegius dan makhluk sosial.

Dari pengertian di atas dapat disimpulan pendidikan humanis merupakan pendidikan yang mengutamakan kepentingan individu untuk mendapatkan segala haknya sebagai manusia yang merdeka.

Dalam teori belajar humanistik, proses belajar harus berhulu dan bermuara pada manusia itu sendiri. Meskipun teori ini lebih banyak menekankan pentingnya isi dari proses belajar, tetapi didalam kenyataan teori ini lebih banyak berbicara tentang pendidikan dan proses belajar dalam bentuknya yang paling ideal. Teori ini lebih tertarik pada ide belajar dalam bentuknya yang paling ideal dari pada belajar seperti apa adanya, seperti apa yang bisa kita amati dalam keseharian. Hamzah (2006:13) menyatakan "Teori belajar ini berusaha memahami perilaku belajar dari sudut pandang pelakunya, bukan dari sudut pandang pengamatnya". 
Peran guru dalam pendidikan humanistik adalah bagaimana guru mampu menjadi failitator dalam tujuan pembelajaran untuk peserta didik agar potensi yang dimilikinya dapat berkembang dengan baik. Peran peserta didik disini bertujuan untuk dapat mengembangkan potensi secara posistif bukan mengembangkan potensi yang negatif.

Sukmadinata dan Syaodih (2007:157) menyimpulkan ciri-ciri guru yang fasilitatif adalah sebagai berikut:

1. Mampu merespon perasaan yang dialami peserta didik.

2. Mampu menggunakan ide-ide dari peserta didik untuk melaksanakan interaksi yang sudah dirancang sebelumnya.

3. Melakukan dialog dan melakukan diskusi dengan peserta didik

4. Dapat menghargai peserta didik

5. Mampu menyesuaikan antara perilaku dan perbuatan

6. Dapat menyesuaikan isi kerangka berpikir peserta didik.

7. Selalu tersenyum pada peserta didik.

Kurikulum 2013 proses pembelajarannya menggunakan pendekatan ilmiah yang harus menyentuh tiga ranah yaitu: ranah sikap, ranah pengetahuan dan ranah ketrampilan. Sementara itu, pendekatan ilmiah yang digunakan harus meliputi penggalian informasi dengan cara: pengamatan, bertanya, percobaan, mengolah data, menyajikan data, kemudian dilanjutkan dengan menganalisis, menalar, menyimpulkan, dan mencipta. Pendekatan ilmiah ini kadang tidak tepat digunakan dalam kondisi dan materi tertentu, tetapi dalam kondisi ini proses pembelajaran harus tetap menerapkan nilai atau sifat nonilmiah.

Majid (2014:211) mengemukakan bahwa dalam proses pembelajaran pendekatan ilmiah yang harus dilakukan adalah meliputi: mengamati, menanya, mencoba, menalar, mengolah, menyimpulkan, menyajikan dan mengomunikasikan. Hal tersebut dapat dijabarkan sebagai berikut:

\section{Mengamati}

Kegiatan ini biasanya disediakan obyek untuk diamati, disimak, didengar ataupun dibaca, dengan hal ini supaya pesarta didik merasa tertantang dan timbul perasaan ingin tahu. 


\section{eL-Tarbauj Barudin}

\section{Menanya}

Setelah selesai proses mengamati dan timbul perasaan ingin tahu guru memberikan kesempatan dan membimbing peserta didik untuk mengajukan pertanyaan mengenai kegiatan pengamatan yang telah dilakukan sebelumnya. Pada kegiatan ini guru harus mampu memberikan kesempatan secara luas kepada peserta didik untuk dapat bertanya.

\section{Mencoba}

Kegiatan mencoba dimaksudkan untuk menggembangkan tujuan belajar. Aktivitas pembelajaran nyata yang dapat dilakukan dalam kegiatan ini adalah sebagai berikut:

a. Menentukan tema atau topik yang sesuai dengan kompetensi

b. Mempelajari cara-cara penggunaan alat dan bahan yang tersedia

c. Mempelajari dasar teoritis yang relevan dan hasil-hasil eksperimen sebelumnya

d. Melakukan dan mengamati percobaan

e. Mencatat fenomena yang terjadi, menganalisis, dan menyajikan data

f. Menarik kesimpulan atas hasil percobaan

g. Membuat laporan dan mengomunikasikan hasil percobaan.

Sebelum kegiatan mencoba dilakukan sebaiknya guru melakukan beberapa hal agar kegiatan ini berjalan dengan baik, diantaranya adalah sebagai berikut:

a. Tujuan dari eksperimen yang dirumuskan terlebih dahulu

b. Perlengkapan disediakan sejak awal

c. Tempat dan waktu diperhitungkan

d. Disediakan kertas kerja untuk pengarahan kegiatan peserta didik

e. Guru memberikan pengarahan.

f. Kertas kerjadibagikan kepada peserta didik.

g. Eksperimen dilakukan dengan bimbingan guru

h. Hasil kerja peserta didik dikumpulkan dan di evaluasi.

\section{Menalar}

Menalar disini maksudnya adalah peserta didik mampu untuk berpikir secara logik kemudian mengaitkan antara konsep dengan 
fakta sehingga peserta didik mampu untuk memahami fakta dan mampu menjelaskan tentang fenomena ilmiah yang ada dalam fakta tersebut.

\section{Mengolah}

Pada proses mengolah peserta didik diharapkan mampu untuk secara aktif dalam bekerjasama saling menghormati, saling berempati, siap menerima masukan dan saling membantu dalam menyelesaikan tugas yang diberikan oleh guru. Guru lebih berperan sebagai manajer belajar.

\section{Menyimpulkan}

Setelah selesai kegiatan mengolah maka peserta didik diminta untuk dapat menyimpulkan hasil. Kegiatan ini bisa dilakukan secara mandiri ataupun secara kelompok tergantung perintah dari guru.

\section{Menyajikan}

Tugas peserta didik yang sudah diselesaikan secara kalaboratif kemudian dikonsultasikan kepada guru untuk dijadikan sebagai bahan laporan tertulis. Bentuk laporan bisa bersifat mandiri ataupun bersifat kelompok.

\section{Mengomunikasikan}

Pada kegiatan ini guru memberikan klarifikasi terhadap hasil pekerjaan siswa, sehingga akan diketahui secara pasti jawaban yang diberikan benar atau masih membutuhkan perbaikan. Proses mengomunikasikan ini akan memberikan rasa puas kepada peserta didik karena ada penghargaan terhadap hasil kerjaannya.

Paradigma dalam pembelajaran abad 21 sangat menekankan kepada kemampuan siswa dapat berpikir kritis, mampu menghubungkan ilmu pengetahuan dengan dunia nyata, menguasai teknologi informasi komunikasi, dan berkolaborasi. Guru hanya berperan sebagai fasilitator dan memberikan motivasi agar peserta didik sadar dan memperoleh tujuan dari pembelajaran, yakni dapat memahami potensi diri dan mengembangkannya. Guru sebagai 


\section{eL-Tarbawj Barudin}

fasilitator harus aktif terlebih terhadap peserta didik yang pasif dalam pembelajaran agar tidak merasa malu, minder ataupun takut untuk bertanya maupun mengemukakan pendapat sehingga tidak tertinggal oleh peserta didik yang aktif dalam kegiatan pembelajaran. Pembelajaran humanistik juga mempunyai kelemahan, jika dalam proses pembelajaran tidak terkontrol maka akan mengakibatkan peserta didik bersikap egois melakukan apa yang diinginkan tanpa batas. Pembelajaran humanistik harusnya mampu memberika arahan yang dapat memancing respons peserta didik agar antusias dalam mengikuti proses pembelajaran dan menghasilkan perubahan yang positif.

\section{Kesimpulan}

Peserta didik harus disiapkan sedini mungkin agar dapat menghadapi era globalisasi dan tuntutan dunia. Abad 21 menuntut penguasaan berpikir tingkat tinggi, berpikir kritis, menguasai teknologi informasi, kemampuan berkolaborasi, dan berkomunikasi. Untuk mengantisipasi hal ini, diperlukan alternatif pendidikan yang memberikan solusi agar manusia mampu berpikir, merasa, berkemauan, dan bertindak sesuai dengan nilai-nilai luhur kemanusiaan. Dalam teori belajar humanistik, proses belajar dianggap berhasil apabila peserta didik mampu mencapai aktualisasi diri serta dapat memahami diri dan lingkungannya .

Pembelajaran humanistik sangat relevan diterapkan dalam rangka untuk mempersiapkan peserta didik menghadapi Abad 21. Pembelajaran humanistik memberikan dorongan agar setiap individu melakukan peningkatan kualitas potensi positif yang ada dalam dirinya sebagai manusia melalui fitrah dalam dirinya. Zaman terus berubah dan tuntutannya pun akan berubah pula, begitupun dengan proses pendidikan akan selau mengikuti perubahannya. Untuk mencapai hasil terbaik dunia pendidikan perlu untuk melakukan berbagai inovasi. Pembelajaran humanistik memberikan arahan yang signifikan dalam pencapaian tujuan ini. 


\section{Daftar Pustaka}

Assegaf, Abd Rahman. (2004). Pendidikan Tanpa Kekerasan: Tipologi, Kondisi, Kasus dan Konsep. Yogyakarta: Tiara Wacana.

Dinn Wahyudin. (2008). Pengantar Pendidikan. Jakarta: Universitas Terbuka.

Majid, Abdul. (2014). Pembelajaran Tematik Terpadu. Bandung: Remaja Rosdakarya

Mas'ud, Abdurrahman. (2004). Menggagas Format Pendidikan Non dikotomik: Humanisme Religius sebagai Paradigma Pendidikan Islam.Yogyakarta: Gama Media.

Sugiarto, Bambang. 2008. Humanisme dan Humaniora (Relevansinya dengan Pendidikan). Bandung: Jalasutra.

Sukardjo. (2009). Landasan Pendidikan (konsep dan Aplikasinya). Jakarta: Raja Grafindo Persada.

Sukmadinata, dan Nana Syaodih. 2007. Landasan Psikologi Proses Pendidikan. Cet. IV, Bandung: Remaja Rosdakarya.

Uno, Hamzah B. 2006. Orientasi Baru Dalam Psikologi Perkembangan. Jakarta: Bumi aksara. 